\title{
Ergonomia do Ambiente Construído e Qualidade Visual Percebida
}

\author{
Ergonomics of the Built Environment and Perceived Visual Quality
}

\author{
LOURIVAL COSTA FILHO \\ Doutor em Desenvolvimento Urbano; UFPE (Curso de Design | PPGDesign | PPErgo) \\ lourival.costa@ufpe.br
}

\section{RESUMO}

As características visuais dos elementos ambientais têm importante impacto na experiência humana, podendo evocar fortes emoções e influenciar o comportamento espacial, levando as pessoas a evitar ou ir a determinados lugares, a partir de suas avaliações e de seus sentimentos. Buscando associar conhecimentos da Estética Ambiental (Estética Empírica + Psicologia Ambiental) à Ergonomia do Ambiente Construído, em prol de diretrizes de projetos que auxiliem a interface humano-ambiente, esta comunicação científica pretende apresentar considerações teóricas e evidências empíricas que norteiem a Qualidade Visual Percebida em ambientes. Nesse intuito, delineou-se uma perspectiva teórica da Estética Ambiental, à medida que vai se discutindo evidências empíricas que examinaram a construção da resposta estética, as características ambientais e as dimensões humanas relevantes para a Qualidade Visual Percebida, procurando, na medida do possível, fazer a associação desses conhecimentos à Ergonomia do Ambiente Construído. $O$ estudo dessa relação demonstra que a resposta estética é um fenômeno complexo que pode variar de acordo com o tipo de observador, tipo de cena e atividade associada considerada, e que podem nortear a Qualidade Visual Percebida em ambientes. Devido à singularidade de cada ser humano e às experiências únicas, a ciência tenta trazer ordem às experiências que parecem variadas, procurando consenso ou princípios universais. Embora inexista consenso para a mesma resposta avaliativa, há alguns pontos em comum entre os indivíduos. A realidade física compartilhada, a fisiologia e a cultura, assim como o treino do olhar, produzem áreas consensuais. A partir desse prisma, relacionam-se perspectivas teóricas de que a preferência ambiental (Qualidade Visual Percebida) é aprimorada pelas características de ordem, moderada complexidade, naturalidade, abertura visual, conservação, e significado histórico (estilo), e que o efeito ambiental para uma grande variedade de lugares é o produto de duas dimensões ortogonais primárias: agradabilidade (dimensão avaliativa) e estimulação (dimensão não-avaliativa), que, em conjunto, produzem duas dimensões avaliativas afetivas, emoção e relaxamento, além de seus opostos complementares, sombrio e aflitivo. Essas perspectivas teóricas revelam bases de projeto de ambientes, além de, mais amplamente, para a melhoria da interação humano-ambiente; enquanto a investigação de aspectos práticos, derivados da aplicação dos resultados dessas pesquisas na metodologia de projeto de ambientes, pode ajudar a transformar a teoria e a pesquisa em realidades físicas.

PALAVRAS-CHAVE: Ergonomia do Ambiente Construído; Estética Ambiental; Qualidade Visual Percebida 